\title{
Performance of jet type singlet oxygen generator of supersonic COIL for optical power system
}

\section{光カシステムにおける超音速化学励起沃素レーザーの新型 Jet type 励起酸素発生器の動作特性}

\author{
Hayato TANAKA、 Hidenori SHIMADA、Masamori ENDO、 and Shuzaburo TAKEDA \\ Department of Electro-Photo-Optics, School of Engineering, Tokai University, 1117 Kitakaname \\ Hiratuka, Kanagawa,259-12 JAPAN \\ TEL:81-463-58-1211(EX.4373),FAX:81-463-58-8360 \\ Kenzo NANRI, Tomoo FUJIOKA \\ Department of Physics, School of Science, Tokai University, 1117 Kitakaname, Hiratuka, Kanagawa \\ 259-12 JAPAN \\ TEL:81-463-58-1211(EX.3708),FAX:81-463-58-8360 \\ Fumio WANI \\ Opto Engineering Department, Kanto Technical Institute Laboratory, Kawasaki Heavy Industries \\ 118 Futatuzuka, Noda, Chiba, 278 JAPAN \\ TEL:81-471-24-0269,FAX:81-471-24-5917 \\ ( Accepted for publication 6 November 1997 )
}

\begin{abstract}
Chemical oxygen iodine laser has various characteristics, which is considered to be effective as an illuminant of the optical power system. New type of SOG can be excited with high efficiency under the high pressure of singlet oxygen as well in the supersonic speed COIL SOG. In this paper we investigated dynamic character of Jet type SOG without buffer gas by using JSOG from the view points of miniaturization and low cost for the production.
\end{abstract}

Keywords: chemical oxygen-iodine laser, singlet oxygen generator, optical power system

\section{I .INTRODUCTION}

光力システムとは、光を「第3のエネルギー」として利用しよ うとするものであり、その為には直接的には電力を用いないで 光エネルギーを発生する光源が必要である。

化学酸素沃素レーザー (COIL:Chemical Oxygen - Iodine Laser) は化学反応によって生成された一重項励起状態の酸 素(励起酸素 $\mathrm{O}_{2}\left({ }^{1} \Delta\right)$ ) と沃素分子 $\mathrm{I}_{2}$ を混合し、励起酸素 $\mathrm{O}_{2}\left({ }^{1} \Delta\right)$ からの近共鳴的なエネルギー移乗によって反転分布 状態となった励起沃素原子が発振するレーザーである。この 酸素一沃素システムは原理的には電気エネルギーを必要と しない純化学レーザーであり、光カシステムの光源として期 待される。以下に COIL の化学反応式を示す。

$$
\begin{aligned}
& \mathrm{H}_{2} \mathrm{O}_{2}+2 \mathrm{KOH}+\mathrm{Cl}_{2} \rightarrow \mathrm{O}_{2}\left({ }^{1} \Delta\right)+2 \mathrm{KCl}+2 \mathrm{H}_{2} \mathrm{O} \\
& \mathrm{nO}_{2}\left({ }^{1} \Delta\right)+\mathrm{I}_{2} \rightarrow \mathrm{nO}_{2}\left({ }^{3} \Sigma\right)+2 \mathrm{I}(\mathrm{n}=3 \sim 6) \\
& \mathrm{nO}_{2}\left({ }^{1} \Delta\right)+\mathrm{I} \rightleftarrows \mathrm{nO}_{2}\left({ }^{3} \Sigma\right)+\mathrm{I}^{*} \\
& \mathrm{I}^{*} \rightarrow \mathrm{I}+\mathrm{h} v(1.315 \mu \mathrm{m})
\end{aligned}
$$

現在は産業用としての開発が主である COIL であるが、 その中で重要であるのが装置の小型化、低コスト化である。 本研究では産業用 COIL の小型化、低コスト化という視点 から、COIL の新型励起酸素発生器 (SOG : Singlet Oxygen Generator）の動作特性を測定することを目的とした。

\section{PRINCIPLE}

本研究で使用している COIL は超音速型と呼ばれるも ので、レーザー媒質であるガスの流れが共振器内で超音速 (マッ八数 1 ～2)まで達するが、このとき共振器の手前で ガス圧力が数十 Torr 必要になる。SOG は式 [1] の反応 より励起酸素 $\mathrm{O}_{2}\left({ }^{1} \Delta\right)$ を生成する。こ SOG 出口でのガス 圧力を上げるために従来の $\mathrm{SOG}$ では希釈ガス $\left(\mathrm{N}_{2} 、 \mathrm{Ar} 、 \mathrm{He}\right)$ を塩素と混合することにより塩素の分圧を下げ、高い励起 効率での高圧力動作を行っている。

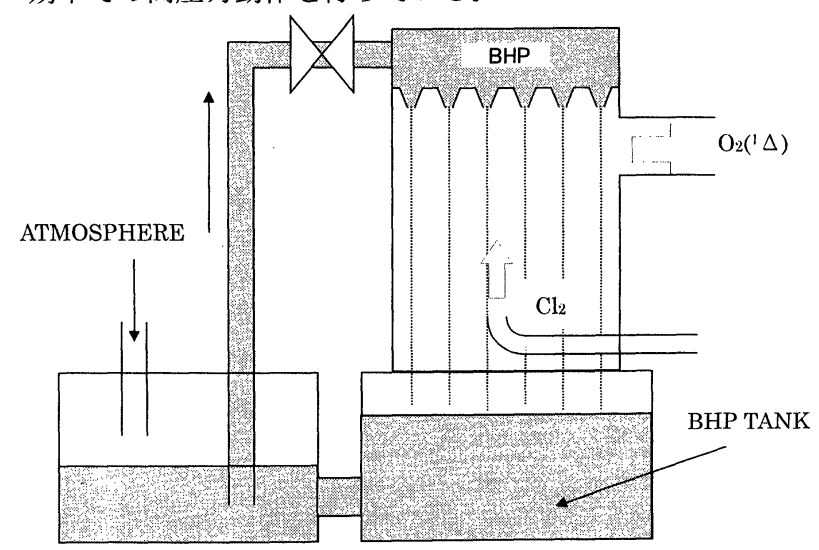

FIG. 1 Schematic of Jet type SOG. 
本研究で使用した Jet type SOG は液柱状にしたアルカ リ性過酸化水溶液(BHP : Basic Hydrogen Peroxide)ジェッ トと塩素ガスを 180 度対向させて反応を起こすものである。 このとき気一液接触面は $4.22\left[\mathrm{~cm}^{-1}\right]$ で、反応領域は $10[\mathrm{~cm}]$ である。また、BHP のジェットを作るノズルの直径は $0.8[\mathrm{~mm}] 、$ 穴数 146[個]である。この SOG の概略図を Fig.1 に示す。BHP 貯蔵タンクは真空になっており、BHP は大 気との差圧を利用して輸送され、ノズルを通りシャワーの ように SOG 内に流れる。この方法では単位体積あたり発 生可能な励起酸素 $\mathrm{O}_{2}\left({ }^{1} \Delta\right)$ の量が従来の SOG より多く、高圧 力動作に有利である。また発生した励起酸素 $\mathrm{O}_{2}\left({ }^{1} \Delta\right)$ が気相中 に拡散するのが速いので BHP との失活が少なく高い励起率で 輸送できる。

\section{III.EXPERIMENTAL}

現在までの段階ではこの Jet type SOG でも SOG 出口の ところで希釈ガス $(\mathrm{He})$ を混合してレーザー発振を行ってい た。しかし、先述のような SOG の特性から今回 SOG のみ で希釈ガスなしでの励起酸素 $\mathrm{O}_{2}\left({ }^{1} \Delta\right)$ の分圧、ガス速度、励 起効率また塩素流量との関係を測定した。

励起酸素 $\mathrm{O}_{2}\left({ }^{1} \Delta\right)$ の分圧の測定には光スペクトルアナライ ザーを用いて励起酸素 $\mathrm{O}_{2}\left({ }^{1} \Delta\right)$ の波長 $1.27 \mu \mathrm{m}$ の自然放出 光を測定することで算出した。また、励起効率 Yは反応効 率 $100 \%$ として、測定場所(SOG 出口)での全酸素圧力中の 励起酸素 $\mathrm{O}_{2}\left({ }^{1} \Delta\right)$ 分圧の割合として出している。

このとき、塩素流量 15 30[mmol]、SOG 内部圧力 20 〜 100[torr]、SOG 出口ガス速度 10〜 $20[\mathrm{~m} / \mathrm{s}]$ であり、BHP 流量は $0.56[1 / \mathrm{s}]$ という実験条件で測定を行なった。

\section{IV.RESULT}

実験の結果を Fig. 2、Fig. 3、Fig. 4 に示す。

Figure 2 では、ガス圧を上げることにより励起酸素どう しの衝突による二量子体の失活が少なくなり励起効率が上 がうている。Figure3では塩素流量を変化さしても励起率が 安定していることがわかる。Figure4より他の SOG に比べて 高圧力下でも数段高い励起効率であり、その性能の高さが 現れている。

これらの結果より Jet type SOG は塩素ガスのみでの高 圧力化、また塩素流量 $15 \sim 30[\mathrm{mmol}]$ という幅広い動作条 件下においても高い励起効率を保っていることがわかった。 また、他の励起酸素発生器の体積と比べても、Fig. 4 に示 されている Bubbler type 、Rotation disk type と Jet type SOG では $3400: 12: 1$ と非常にコンパクトである。

\section{V.CONCLUSION}

Jet type SOG は塩素のみでの動作においても、高い圧 力でかつ高い励起効率での励起酸素 $\mathrm{O}_{2}\left({ }^{1} \Delta\right)$ を生成すること が確認できたことにより、超音速型 COIL の希釈ガスなし
での低コスト化、またコンパクト化に大きく近づいたと考 えられる。

今後は BHP のジェットノズルなどの条件を変化するよ うに設計し、より高い性能が得られるように Jet type SOG の最適化を行うと共に、希釈ガスなしでの超音速型 COIL のレーザー発振の実験を行う予定である。

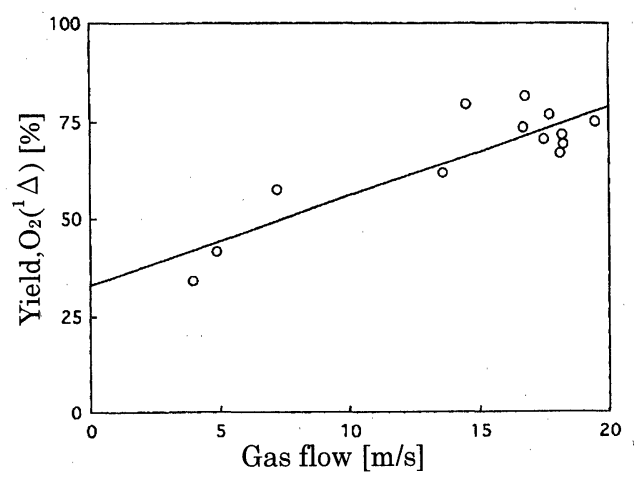

FIG.2.Gas flow rate vs. yield $\left(\mathrm{Cl}_{2}\right.$ flow, $\left.20 \mathrm{mmol} / \mathrm{s}\right)$

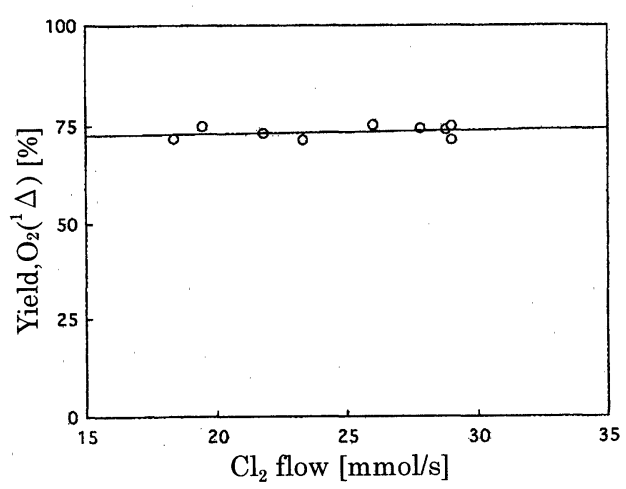

FIG.3.Cl2 flow vs. yield (In SOG press. 20Torr)

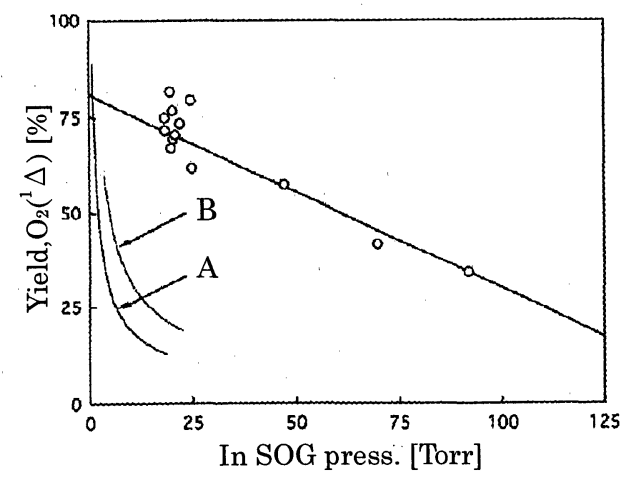

FIG.4.In SOG pressure vs. yield (Cl2 flow, $20 \mathrm{mmol} / \mathrm{s})$ A:Bubbler type,B:Rotation disk type

\section{REFERENCE}

${ }^{1}$ M.V.Zagidullin,"High Efficient Jet O2(1 $\left.\Delta\right)$ Generator" Sov.J.Quant.Elestern21,pp747(1991)

'97 SAS Intelligent Symposium 